Özbay, M. ve Memiş, M. R. (2015). Beyin Araştırmalarına Dayalı Öğrenme ve Yazma Eğitimi. Ana Dili Eğitimi Dergisi, 3(2), 1-34.

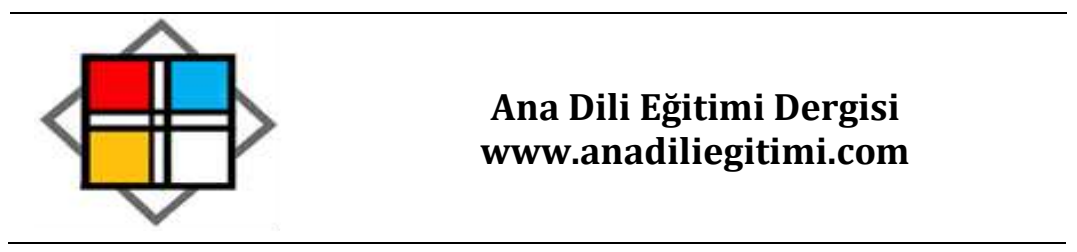

\title{
Beyin Araştırmalarına Dayalı Öğrenme ve Yazma Eğitimi
}

\author{
Murat Özbay \\ Muhammet Raşit Memiş*
}

Gönderilme: 27.03.2015 / Düzeltme: 04.04.2015 / Kabul Edilme: 08.04.2015

\section{Öz}

Günümüz dünyasının değişen koşulları eğitim alanında birçok yeni yaklaşımı ortaya çıkarmışır. Bu yaklaşımlardan biri de beyin araştırmalarına dayalı öğrenmedir. Bu yaklaşım anlamlı bir öğrenmenin gerçekleşebilmesi için beynin işleyiş kurallarının kabul edilmesini ve öğretimin de zihnin bu kurallarına göre şekillendirilmesi gerektiğini iddia etmektedir. Beyin araştırmalarına dayalı öğrenmenin ilkeleri ile ana dili öğretiminin hedef ve ilkeleri dikkate alındığında bu yaklaşımla yapılacak bir öğretimin Türkçe eğitiminin nihaî hedefi olan dört temel dil becerisinin geliştirilmesinde oldukça etkili olacağı düşünülmektedir. Bu çalışmada beyin araştırmalarına dayalı öğrenme yaklaşımı ana hatlarıyla ele alınmış, yaklaşımın yazma eğitimiyle ilişkisi değerlendirilmiş, bu yaklaşıma uygun bir öğretim planına yer verilerek bunun yazma eğitiminde nasıl kullanılabileceğini gösteren bir uygulama örneği hazırlanmıştır.

Anahtar kelimeler: Beyin araştırmalarına dayalı öğrenme, yazma eğitimi, Türkçe eğitimi.

\section{Brain Researches Based Learning and Writing Education}

\begin{abstract}
Changed conditions of today's World have caused a lot of new approaches in education. One of these approaches is Brain Researches Based Learning. This approach asserts that in order to realize a meaningful learning, it is necessary to admit functioning rules of the brain and education should be shaped in accordance with these rules. When taking into consideration principles of the brain researches based learning and aims and principles of mother tongue teaching, it is believed that teaching with this approach would be efficient in developing four basic language skills which is ultimate goal of Turkish education. In this study, essentials of brain researches based learning were handled, relation between this approach and writing education was considered, instructional plan that is suited to this approach was given and an application example that shows how this plan might be used in writing education was prepared.
\end{abstract}

Keywords: Brain researches based learning, writing education, Turkish education.

\footnotetext{
${ }^{*}$ Prof. Dr., Gazi Üniversitesi, Gazi Eğitim Fakültesi, Türkçe Eğitimi Bölümü. Ankara. e-posta: mozbay@gazi.edu.tr

${ }^{* *}$ Arş. Gör., Gazi Üniversitesi, Eğitim Bilimleri Enstitüsü, Türkçe Eğitimi Ana Bilim Dalı. Ankara. e-posta: muhammet.memis@omu.edu.tr
} 


\section{Giriş}

Küreselleşen ve bilgi çağı olarak adlandırılan günümüz dünyası teknolojik gelişmeler neticesinde değişmektedir. Bu değişimlerin her alana olduğu gibi eğitime de önemli yansımaları olmuştur. Eğitim alanında ortaya çıkan modern yaklaşımlar eğitime yeni bakış açıları ve kavramlar getirmiştir. Geleneksel eğitim anlayışının aksine öğretim yerine öğrenmeyi vurgulayan yeni anlayışta eğitim, öğrenci merkezli bir hâle dönüşmüştür. Önceki anlayışta öğretim herhangi bir öğretmen tarafından gerçekleştirilebilen doğrusal bir yapıdayken, yeni anlayışta karmaşık ve uzun bir süreç olarak ele alınmakta ve öğretim sürecinin yalnızca ilgili alanda eğitim alıp uzmanlaşmış öğreticiler tarafından gerçekleştirilebileceği kabul edilmektedir.

Bu noktada, öğretmenin öğrenme-öğretme sürecinde etkili eğitim ortamları hazırlama ve öğretim etkinlikleri düzenleme gibi öğreticilikle ilgili rolleri ön plana çıkmaktadır. Yeni anlayışta öğretmenin ön plana çıkarılan bu rolleri etkili şekilde yerine getirmesi ise, öğretmenin alternatif öğretim stratejisi, yöntem ve tekniklerini bilme ve bunları uygulama becerisine sahip olmasını gerektirmektedir (Açıkgöz, 2003; Bursky, 2002; Şenatalar, 2004 akt: Akpınar ve Gezer: 2010: 2). Bu doğrultuda, değişen eğitim anlayışının ortaya çıkardığı yeniliklerin eğitim sürecine yerleşebilmesi için tanıtılması, irdelenmesi, geliştirilmesi ve eğitim yapılan farklı alanlara uyarlanması gerekmektedir. Ortaya çıkan yeni yaklaşımlardan birisi de beyin araştırmalarına dayalı öğrenmedir. Muhtelif kaynaklarda beyin temelli öğrenme olarak isimlendirilen bu yaklaşım, beyinle ilgili yapılan araştırmaların sonuçları doğrultusunda beynin işleyiş kurallarını dikkate alarak eğitimin bu kurallara göre düzenlenmesini amaçlamaktadır.

Ülkemizde bugüne kadar beyin araştırmalarına dayalı öğrenme üzerine yazılan tez ve makaleler çoğunlukla fen bilgisi ve sosyal bilgiler eğitimi alanlarındayken ana dilinin öğretimine çok uygun olan bu yaklaşım Türkçe eğitimi alanında henüz yeterince dikkate alınmamıştır.

Literatür tarama yöntemiyle hazırlanan bu çalışmanın amacı beyin araştırmalarına dayalı öğrenme yaklaşımı hakkında bilgi vermek, yaklaşımın yazma eğitimiyle ilişkisini değerlendirmek, bu yaklaşıma uygun bir öğretim planına yer vererek bu planın yazma eğitiminde nasıl kullanılabileceğini gösteren bir uygulama örneği hazırlamaktır.

\section{Beyin Araştırmalarına Dayalı Öğrenme}

Beyin hakkında bilinenler; sinir sistemi, beyin, beynin biyolojik yapısı, algı, zihin ve öğrenme üzerine yapılan çalışmalarından gelmektedir. Beyin araştırmalarına dayalı öğrenme nörologlar, biyologlar, psikologlar, doktorlar ve eğitimcilerin çalışmalarının birleştirilmesiyle derlenmiştir (Connell, 2009: 28). Bu çalışmalardan elde edilen sonuçlar doğrultusunda beynin doğal işleyişinde en iyi nasıl öğrendiği tespit edilmeye çalışımış, beyin temelli öğrenme çatısı altında belli ilkelere ve düzene bağlanmıştır. 
Beyin Araştırmalarına Dayalı Öğrenme ve Yazma Eğitim

Beyin araştırmalarına dayalı öğrenme insan beyninin işlev ve yapısına dayanan, beyin ile ilgili bütün alanlarla bağlantı kuran bir öğrenme yaklaşımıdır. Bu yaklaşım, öğrenmeyi beynin yapısı ve fonksiyonları üzerine inşa eder ve öğretime yönelik çıkarımlarda bulunur (Caine ve Caine, 1991). Beyin temelli öğrenme, anlamlı öğrenme için beynin işleyiş kurallarının kabul edilmesini ve öğretimin zihindeki bu kurallara göre örgütlenmesini içerir. Beyin temelli öğrenme, sağduyu, insan deneyimleri ve beyin araştırmalarının, sınıf ortamında nasıl faydalı araçlar ve ilkeler ortaya koyduğunu anlatan kapsamlı bir kavramdır (Duman, 2007: 66).

Beyin araştırmalarına dayalı öğrenme; öğrenciye bilginin verilmesinden ziyade bunu öğrencinin kendisinin almasının sağlandığı bir ortamda sürekli yaşantısı ile ilgili örnekler verilerek öğrencinin beynini aktif tutan, onu ezberlemeye değil düşünmeye sevk eden, öğrencinin beynini aynı anda birçok noktada harekete geçiren, öğrencinin merakını uyandırarak yenilikçi ve keşfedici bireyler hâline getirmeyi amaçlayan bir öğrenme yaklaşımıdır (Caine ve Caine, 1995 akt. Polat, 2014: 268). Beyin temelli öğrenme beynin nasıl çalıştığını en iyi şekilde bilerek, maksimum öğrenmenin gerçekleşme yollarını keşfederek yapılan öğrenmeyi benimser. (Carolyn, 1997).

\section{Beyin Araştırmalarına Dayalı Öğrenmenin Esasları}

Beyin araştırmalarına dayalı öğrenmenin en kapsamlı amacı, bilgi ezberlemeyi bırakıp anlamlı öğrenmeye geçmektir (Caine ve Caine, 1990: 69). Bunun yanı sıra öğrencilerin beyinlerinin her iki yarım küresini de dengeli bir şekilde kullanmalarını sağlamak, öğrencilerin kendi problemlerini sistematik bir biçimde çözmeleri için yol göstermek, bilgi, işlem ve davranışa yansıyacak bilimi öğretmek beyin temelli öğrenmenin amaçları arasındadır (Nuangchalerm ve Charnsirirattana, 2010: 143).

Beyin araştırmalarına dayalı öğrenmenin amaçlarına ulaşabilmesi için uygulamada bazı hususlara dikkat edilmelidir:

- Öğrencilere yeni konuya geçilmeden bir süre önce haber verilmeli, öğrenilecek konu hakkında merak uyandırılmalı ve beklenti oluşturulmalıdır.

- Öğrencilere derste ve dersten sonra yargılamaktan uzak geri dönütler verilmeli, onların geçmiş öğrenmeler ile yeni konular arasında bağlantı kurmaları sağlanmalıdır.

- Öğrenciler dersin her aşamasında aktif olmalıdır. Onlara bir şeyin nasıl yapılacağı anlatılmamalı, etkinliklerle o işi yapmaları sağlanmalıdır.

- Öğrencilere kendi öğrenmelerini kontrol edebilme becerisi kazandırılmalıdır.

- Öğrencilerin iş birliği içinde çalışmalarını destekleyecek etkinlikler hazırlanmalıdır.

- Öğrencilerin hem kendileri hem de sınıfın tamamı için hedef belirlemesi sağlanmalıdır.

- Öğrenilen bilgilerin kısa süreli bellekten uzun süreli belleğe geçmesi için öğrencilere yeterli zaman verilmeli ve bu zaman müzik dinletme, ara verme, yemek yeme gibi etkinliklerle zenginleştirilmelidir. 
- Öğrencilerin stres düzeyi dikkatli bir şekilde takip edilmelidir. Stres eğer dozunda olursa öğrencinin motivasyonu arttığı için başarı da artacak, fazla olursa başarı düşecektir.

- Öğrencilere mümkün olduğunca çok sayıda ve farklı öğrenme stillerine hitap eden etkinlikler hazırlanmalıdır.

- Öğrencilere çalışmalarını ve çalışmalarının sonucunda elde ettikleri başarılarını kutlayabilecekleri bir ortam sunulmalıdır.

- Derslerde işlenen konular öğrencilerin deneyimleriyle ilişkilendirilmelidir. Hatta konu seçimi yapılırken öğrencilerin günlük yaşamlarında çokça karşılaşabilecekleri konulara öncelik verilmelidir.

- Etkinlikler gerçekleştirilirken öğrencilere sınıf içinde serbestlik hakkı verilmeli, istediği yerde ve istediği kişi ile oturması sağlanmalıdır.

- Hareket etme ve müzik dinleme, öğrenmeye katkı sağlayan iki unsurdur. Etkinlikler sırasında bu unsurlara yeterince yer verilmelidir (Jensen, 2000; Caine ve Caine, 1991; Duman, 2007: 321333).

\section{Öğretim Süreci}

Öğrenmenin anlamlı ve kalıcı olmasını amaçlayan beyin temelli öğrenmede öğretim üç temel süreç üzerine inşa edilmiştir. Bu süreçler kaynaklarda "rahatça almaya hazır olma, derinlemesine daldırma ve aktif süreçleme" şeklinde isimlendirilmektedir.

Rahatça almaya hazır olma sürecinde öğrencilerin korku, stres ve kaygılardan uzaklaşması, kendilerini güvende hissetmesi ve öğrenme isteklerinin artması sağlanmaya çalışılır. Derinlemesine daldırma sürecinde öğrenciler karşılaştıkları içeriğe yoğunlaşır ve bilgi edinirler. Aktif süreçleme'de ise öğrenilen bilgiler öğrenci tarafından anlamlı bir şekilde düzenlenir ve içselleştirilir.

Bu süreçler doğrultusunda hazırlanacak bir ders için Jensen yedi aşamalı bir öğrenme planı önermiştir. Bunlar açıklama, motivasyon, başlama ve edinim, ayrıntıya girme, belleğe kodlama, doğrulama ve öz güven kontrolü, kutlama aşamalarıdır (Jensen, 2008: 215-217).

İlgili aşamalar beyin temelli öğretim süreçleri dikkate alınarak şu şekilde sınıflandırılabilir:

\section{RAHATÇA ALMAYA HAZIR}

OLMA

1- Açıklama

2- Motivasyon
DERINLEMESINE DALDIRMA

3- Başlama ve Edinim

4- Ayrıntıya Girme

5- Belleğe Kodlama
AKTIF SÜREÇLEME

6- Doğrulama ve Öz Güven Kontrolü

7- Kutlama 
1. Açıklama: Açıklama aşamasında ayrıntılara girmeden önce yeni öğrenmelerin genel bir görüntüsü sunulur ve beynin kavramsal haritalar oluşturmasına yardım edilir. Bu aşamada dikkat edilmesi gerekenler ve yapılabilecekler şunlardır:

- Beynin iyi bir şekilde beslenmesi için bol su içme teşvik edilir.

- Eğitim ortamı öğrencilerin ilgisini çekecek şekilde yeniden düzenlenir.

- Sabah ve öğleden sonra yapılacak etkinlikler tasarlanırken beynin gün içindeki çalışma kapasitesi dikkate alınır.

- Öğrencilerin ilgileri ve deneyimleri keşfedilmeye çalışılır.

- Öğrenme ortamına konuyla ilgili renkli görsel unsurlar asılır.

- Öğrenciler için çok sayıda ve onların hareket etmelerine imkân veren etkinlikler hazırlanır.

- Derse başlamadan önce öğretmen ve öğrenciler beklentilerini söylerler.

- Panoya yeni konuyla ilgili genel bir bakış açısını yansıtan kavram haritaları asılır.

- Öğrenmeyi öğrenme becerileri ve hafızada tutma stratejileri öğretilir.

- Öğrencilerden kendi hedeflerini belirlemeleri ve her ünite için sınıf hedeflerini tartışmaları istenir.

2. Motivasyon: Öğrencilerin güdülenmeye çalışıldığı aşamadır. Öğrenilecek konuyla ilgili merak ve heyecan uyandıracak etkinlikler düzenlenir. Bu aşamada şunlar yapılabilir:

- Konuyla ilgili bir bağlam oluşturulur.

- Konuyla öğrencilerin geçmiş ve günlük yaşantıları arasında bağ kurulmaya çalışılır.

- Öğrencilere konunun onlar için kişisel değeri hakkında sorular yöneltilir.

- Öğrencilere mutlaka gerçek bir deneyim sunulur. Örneğin gezi düzenlenir, deney yapılır ya da bir konuşmacı derse getirilir.

- Konunun farklı disiplinlerle bağlantısı gösterilmeye çalışılır.

- Öğrencilerin ilgisini çekmek için kısa bir hikâye vb. anlatılır.

3. Başlama ve Edinim: Bu aşama derinlemesine daldırma sürecinin bir parçasıdır. Öğrenci mümkün olduğu kadar içeriğe yoğunlaştırılır. Başlama ve edinim aşamasında şunlar yapılabilir:

- Öğrencilere örnek olay, deney, okul gezisi, röportaj, uygulamalı etkinlikler vb. yardımıyla somut öğrenme deneyimi sağlanır.

- Çoklu zekâya hitap eden etkinlikler hazırlanır.

- Öğrenciler araştırma, tasarlama, bulma ve yapılandırma unsurlarını içeren grup şeklinde çalışabilecekleri projelere yönlendirilir.

- Öğrencilere skeç veya tiyatro yaptırılır, reklam tasarlatılır ya da sınıf/okul gazetesi hazırlatılır.

- Öğrencilerin konuyu araştırıp keşfedebilmeleri için onlara yeterli sayıda ve farklı duyulara hitap eden materyal seçeneği sunulur. 
- Konuyla ilgili videolar izletilir ve sunumlar yapılır.

4. Ayrıntıya Girme: Konuyla ilgili detaylara yer verilen ve öğrencilerin öğrendikleri üzerine aktif bir şekilde düşünmesinin sağlandığı aşamadır. Ayrıntıya girme aşamasında şunlar yapılabilir:

- Öğrencilere bir önceki aşamada öğrendikleriyle ilgili açık uçlu sorular sorulur.

- Öğrenilen konu başka disiplinlerle ilişkilendirilmeye çalışılır.

- Öğrencilerin konuyla ilgili araştırma yapmak üzere kütüphaneyi ve interneti kullanmaları sağlanır.

- İşlenen konuyla ilgili varsa video, film, tiyatro vb. izletilir.

- Küçük gruplar hâlinde tartışma yaptırılır ve gruplardan tartışmanın sonuçlarını sınıfa sunmaları istenir.

- Öğrencilerden tek başlarına ya da grup hâlinde kavram haritaları hazırlamaları istenir.

- Sınıfta tartışma, forum, makale yarışması gibi etkinlikler düzenlenir.

- Konudan öğrenilenlerle ilgili soru cevap etkinliği yapılır.

- Öğrencilerden konunun bir bölümüne hazırlanması ve bazen bir gruba bazen de tüm sınıfa konuyu sunması istenir.

5. Belleğe Kodlama: Beyin öğrenmeyi bir anda değil zaman içinde gerçekleştirir. Belli bir süreden sonra yorulur ve dinlenmeye ihtiyaç duyar. Ayrıca beynin öğrendiği bilgileri belleğe kodlayabilmesi için belli bir dinlenme zamanı gerekir. Bu aşamada bahsedilen hususlar dikkate alınarak şunlar yapılabilir:

- Öğrenmeye bir süre ara verilir.

- Öğrencilere müzik dinletilir.

- Öğrenciler ikili gruplar hâlinde konuyla ilgili konuşmak üzere yürüyüşe çıkarııır.

- Rahatlama ve esneme egzersizleri yaptırılır.

- Öğrencilerden öğrendikleri konuyla ilgili olarak aileleri ve arkadaşlarıyla fikir alışverişinde bulunmaları istenir.

- Öğrencilere öğrendikleri konularla ilgili günlük tutturulur.

6. Doğrulama ve Öz Güven Kontrolü: Öğrencilerin öğrenmelerini değerlendirdikleri, eksiklerini ve yanlışlarını fark ederek düzeltmeye çalıştıkları aşamadır.

- Öğrencilerden öğrendiklerini bir rapora dönüştürmeleri ve arkadaşlarına sunmaları istenir.

- Öğrenciler konuyla ilgili çeşitli türlerde metin yazmaya teşvik edilir.

- Öğrenilenlerle ilgili bir konuda drama çalışması yaptırııır.

- Sözel ya da yazılı olarak kısa bir sınav yapılır.

- Öğrencilerin birbirlerini değerlendirmeleri sağlanır. 
7. Kutlama: Duygular öğrenmede çok etkilidir. Öğrenmelerin duygularla bütünleşmesi onların kalıcı olmasını sağlar. Bu yüzden bitirilen her yeni konunun sonunda öğrencilerin kutlama yapması sağlanmalıdır. Bu aşamada şunlar yapılabilir:

- Sınıfa yiyecek ve içecek getirilir ve getirilenlerin paylaşılması özendirilir.

- Sınıf süslenir ve müzik açılır.

- Ortaya konulan projeleri izlemek üzere diğer sınıflar, aileler ya da öğretmenler davet edilir.

- Projeleri sunduktan sonra katılımcılarla birlikte kısa ve sade bir kutlama yapılır (Jensen, 2008: 215-217).

\section{Beyin Araştırmalarına Dayalı Öğrenme ve Türkçe Eğitimi}

Dil genel anlamıyla insanlar arasında anlaşmayı sağlayan en yaygın ve en güçlü araç olarak tanımlanmaktadır. Dilin bu işlevinden daha önce gelen özelliği ise insan beyninin düşünme aracı olmasıdır. Beynin en önemli soyut faaliyeti olan düşünme, dil olmadan gerçekleşemez. İnsanların düşünmelerini, duygu, düşünce ve isteklerini ifade etmelerini, bilgi edinmelerini ve iletişim kurmalarını sağlayan dilin, beynin öğrenmeyi gerçekleştirmesinde de kilit bir rolü vardır. Bundan başka insanın yaşamı boyunca öğreneceği her şey dil üzerine kurulup gelişecek ve bellekte dil aracılığıyla kodlanıp saklanacaktır. Burada bahsedilen dil ana dilidir. Bir kişinin sağlıklı düşünebilmesi, etkili iletişim kurabilmesi ve herhangi bir konuda kalıcı bir öğrenme gerçekleştirebilmesi için ana dilini doğru bir şekilde öğrenmesi gerekmektedir. Bu açıdan ana dili eğitimi bütün derslerin temelini teşkil eder.

Beyin üzerine yapılan çalışmalarda, beynin dili nasıl öğrendiği konusunda da birtakım sonuçlara ulaşılmıştır. Bu sonuçlar Dhority ve Jensen (1998) tarafından şu şekilde belirtilmiştir:

Dil öğrenimi beynin bütününün çalışmasını gerektirir.

Dil öğrenimi hem parçaların hem de bütünün bir süreç içerisinde verilmesini kapsar.

Beyin bir dil içgüdüsüne sahiptir.

Beynin işleyişinden yola çıkarak en iyi nasıl öğrendiği konusunda ilkeler ortaya koyan beyin araştırmalarına dayalı öğrenme yaklaşımından Türkçe öğretiminde de mümkün olduğunca yararlanılmalıdır. Türkçe öğretim programında dört temel dil becerisinin birbirinden ayrı düşünülemeyeceği, tüm becerilerin birbiriyle ilişkilendirilerek bütüncül bir şekilde ele alınması gerektiği belirtilmiştir. Beyin araştırmalarına dayalı öğrenme de tüm öğrenmelerin birbiriyle ilişkili olduğunu ve eğitimin bu yönde düzenlenmesi gerektiğini savunmaktadır. Bu açıdan bakıldığında iki anlayış birbiriyle örtüşmektedir.

Beyin temelli öğrenmeye uygun olarak düzenlenen bir öğretimin Türkçe öğretim programında yer alan "anlama, sıralama, ilişki kurma, sınıflama, sorgulama, eleştirme, tahmin etme, analiz sentez yapma, yorumlama ve değerlendirme becerilerini geliştirme" , "Yapıcı, yaratıcı, akılcı, eleştirel ve doğru düşünme yollarını öğrenmeleri, bunları bir alışkanlık hâline getirme" , "duygu, düşünce ve hayal 
dünyalarını geliştirme" (MEB: 2006: 4) genel amaçların gerçekleştirilmesine ve "eleştirel düşünme, yaratıcı düşünme, iletişim kurma, problem çözme, araştırma, karar verme, bilgi teknolojilerini kullanma ve girişimcilik" (MEB: 2006: 5) temel becerilerinin kazandırılmasına yardım edeceği düşünülmektedir.

\section{Beyin Araştırmalarına Dayalı Öğrenme ve Yazma Eğitimi}

Ana dili öğretiminin üzerine kurulduğu dört temel beceriden biri olan yazma, bunların içerisinde en son kazanılan beceridir. Yazma çeşitli kaynaklarda; duygu, düşünce, istek ve olayların belli kurallara uygun olarak birtakım sembollerle anlatılması (Özbay, 2011: 115), duyduklarımızın, düşündüklerimizin, tasarladıklarımızın, görüp yaşadıklarımızın yazı ile aktarılması (Sever, 2004: 24), beyinde yapılandırılmış bilgilerin yazıya dökülmesi (Güneş, 2007: 159), yazarın amacı ve bakış açısına göre bilgilerin zihinde gözden geçirilmesi, seçilmesi ve kelimelerin buna göre sıralanması süreci (Fayol, 1997, akt. Güneş, 2007: 161) ve bilginin elde edilmesi ve ifade edilmesi ile ilgili süreçlerden oluşan bir beceri (Carter vd., 2002: 246) olarak tanımlanmaktadır.

Türkçe Öğretim Programı́nda yer alan düşünme, anlama, sıralama, ilişki kurma, sınıflama, sorgulama, eleştirme, tahmin etme, analiz sentez yapma, yorumlama gibi kazanımları bünyesinde barındıran yazma becerisinin temel amacl; öğrencilerin dil, iletişim, öğrenme, anlama, zihinsel, sosyal ve zihinsel bağımsızlık becerilerini geliştirmektir (Güneş, 2007: 162-163). Türkçe Öğretim Programı'nda ise yazma becerisinin geliştirilmesiyle; öğrencilerin duygu, düşünce, hayal, tasarı ve izlenimlerini dilin imkânlarından yararlanarak ve yazılı anlatım kurallarına uygun şekilde anlatabilmelerinin, yazmayı kendini ifade etmede bir alışkanlığa dönüştürmelerinin ve yazma yeteneği olanların bu becerilerini geliştirmelerinin amaçlandığı belirtilmektedir (MEB: 2006: 7).

Yazma eğitiminin amaçlarına ulaşabilmesi ve kazanımlarının kalıcı olabilmesi için dikkat edilmesi gereken birtakım hususlar bulunmaktadır. Bunlar yazma eğitiminin ilkeleri olarak da adlandırılabilir:

Yazma becerisi yazı yazmakla kazanııı. Bu açıdan yazma eğitiminin temel ilkesi yazdırmaktır. Bu yüzden öğrencilere bol bol uygulama yaptırılmalıdır.

Öğrenciler, bir konu üzerinde kendi bilgi, yaşantı, deney, izlenim ve duygularını, kendi sözcük dağarcı̆̆ıyla, özgürce bildirmeye yönlendirilmelidir.

Öğrencilerin kendi düzeylerine uygun duygu, yaşantı ve bilgilerini anlatma olanağı verecek konular seçilmeli, bireysel farklılıklar göz önünde bulundurulmalıdır.

Sınıfta, yazmaya istek havası uyandırılmalıdır; bu hava yazanları isteklendirerek, çekingenleri yüreklendirerek, yazdıklarını birbirine okuma alışkanlığı oluşturarak, yazma yarışmaları düzenleyerek, okulda gazete, dergi çıkararak yaratılabilir.

Yazma çalışmalarında öğrenci daima merkeze alınmalıdır.

Yazma çalışmaları hayatla ilişkilendirilmeli, günlük tutma, anı yazma, rapor oluşturma vb. etkinliklerle öğrencilere yazmanın zevkli yanları gösterilmelidir. 
Yazılan yazılar sınıf ortamında yapıcı bir yaklaşımla eleştirilmelidir.

İyi yazabilmesi için öğrencide kendine karşı güven uyandırılmalıdır.

Öğrenci, yazısını kendisinin de kabul etmiş ve benimsemiş olacağı bir amaç için yazmalıdır.

Öğrencilerin düşünceleri önemsenmeli, etkinliklerle üretilen ürünlerden arşiv oluşturulmalıdır (Demirel, 1999: 59-60; Özbay, 2011: 118-120; Göğüş, 1978: 240-242; Okurer, 1997: 52- 53; Yılmaz, 2006: 212-214 akt. Göçer, 2010: 181-182).

Yazma becerisini mekanik olarak değil, eleştirel bir düşünme süreci olarak algılamak lâzımdır. Bunun için öğrencilerin dinledikleriyle okuduklarını iyi anlamaları ve bunları beyinlerinde işlemeleri gerekmektedir. Yazma sürecine, beyinde işlenmiş bilgilerin gözden geçirilmesiyle başlanmaktadır. Öncelikle yazının amacı, yöntemi, konusu ve sınırları belirlenerek yazılacak bilgiler seçilmektedir. Seçilen bilgiler çeşitli zihinsel işlemlerden geçirilerek yazılmaktadır. Bilgilerin doğru olarak yazııması, zihinsel becerilerin gelişimi ve düşünmeyle de ilişkilidir (Demir, 2012: 344).

Beyin araştırmalarına dayalı öğrenmenin ilkeleri ve önerdiği öğretim yöntemleri göz önüne alındığında, bu yaklaşıma uygun olarak düzenlenecek bir öğretimin yazma eğitimin ilkeleri ile uyumlu olacağı ve Türkçe öğretim programında yer alan yazma becerisi amaç ve kazanımlarının gerçekleştirilmesine yardım edeceği düşünülmektedir. Aşağıda beyin araştırmalarına dayalı öğrenmenin yazma becerisinin geliştirilmesinde nasıl kullanılabileceğine örnek olması amacıyla hazırlanan ve ilköğretim 7. sınıf düzeyine uygun olduğu düşünülen etkinlikler yer almaktadır:

\section{Uygulama}

\section{Komşusuzluk}

Bütün efendiliğimi ve nezaketimi takınıp sesime nazik bir ton vererek komşuma "lyi akşamlar!" diyorum. Apartman kapısında nadir karşılaşmalarımızdan biri bu. "lyi akşamlar!" diyor, o da. Birinci katta oturuyor. Adı Fahrettin miydi? Yok Fehmi, belki de Faruk'tu... Bir sabah da alt katımızda oturanla karşılaşıyorum. O genç biri, yeni evli. Adını duyduysam da hatırlamıyorum. "Merhaba, günaydın!" diyorum. Samimi cevap veriyor hatta gülümsüyor: "Günaydın!"

Nazikçe gülümsüyorum. Ben iyi, zararsız bir adamım, diyor sesim. Ne olur "lyi akşamlar!" ve "Günaydın!" dan başka, bir kelimecik daha konuşabilseydik. "Nasılsın?" filan desek birbirimize, "Çoluk çocuk iyi mi?" desek. Olmuyor işte. Bütün samimiyetimi, nezaketimi takınıp selam vermeme rağmen, komşularımla bir kelimenin ötesinde konuşacak şey bulamıyorum.

Bazen bu şansı yakalamıyor değilim aslında. Apartman kapısının kapalı olduğu zamanlar oluyor. Anahtarımızı almamış oluyoruz. Kapıda beş on saniye, komşularımdan biriyle bekleme mecburiyetinde kalıyorum. Ama o saniyeler de uzadıkça uzuyor. "iyi akşamlar!" veya "Merhaba!" dan sonra bir şeyler söylemek gerekiyor. Bir türlü denkleştiremiyorum cümleyi ve sıkılıyorum... "Kapı bir an önce açılsa da yukarı çıksam." diyorum. Saniyeler geçmek bilmiyor. Kapı açılıyor, bu sefer de merdivenleri birlikte çıkma problemi var. Hem merhabalaşmışız hem de iki yabancı gibi hiç konuşmadan merdivenleri çıkacağız.

Kabullenemiyorum bunu. Geride kalıyorum. Kapıyı biraz oyalanarak kapatıyorum. Oysa kapı kendiliğinden kapanıyor. Sonra posta kutusuna bakıyorum. İçinde bir şey olmadığını bile bile kapağını açıp kapatıyorum. O zamana kadar komşum çoktan dairesine çıkmış oluyor. Ben de rahat bir nefes alıyorum, gönül rahatığı ile merdivenleri çıkıp evimin kapısını çalıyorum. 
Ara sıra alt kattaki komşumuz müzik setinin sesini anormal bir şekilde açıyor. Aslında kızıyorum. "Ayıp oluyor kardeşim!" demek geliyor içimden. Hatta ben de aynısını yapayım mı, diye düşündüğüm oluyor. Fakat sonra vazgeçiyor, bu düşüncemden ötürü kendime kızıyorum. Keşke her gün yapsa bunu, diyorum. Böylece ben de bir komşum olduğunu, yalnız olmadığımı; bana yakın bir yerde, hemen alt katımda insanların yaşadığını, istesek sesimizi birbirimize ulaştırabileceğimizi düşünüp mutlu olurdum... Insanın yakınında bir komşusunun olduğunu bilmesi hatta ona kızabilmesi bile güzel şey!

Geçenlerde bir yazar da komşusuzluktan yakınıyordu köşe yazısında. Hatta bir "komşular günü" ilan edilmesini bile teklif ediyordu. Komşusuzluktan ben de müştekiyim ama şu özel günleri oldum olası sevmem. Bir "komşular günü" oldu diyelim, onun da diğer anlamsız "özel günler" in akıbetine uğramayacağını kim söyleyebilir? Bir kavramın, bir olayın, kişsinin veya nesnenin "özel bir gün" ü oldu mu, bilin ki o, hayatın dışına çıkmıştır. Henüz böyle bir "özel gün" ü yok ama "komşuluk" da yavaş yavaş çıkıyor hayatımızdan. "Komşular günü" adını vereceğimiz gün, geçmişteki güzel komşuluk ilişkilerini anlatıp tatlı hatıraları yâd etmekten başka ne ifade eder? Ne eski insanları geri getirebiliriz ne de o güzel komşulukları...

Komşuluk ilişkilerimiz neden zayıfladı, komşularımızın adını niçin bilmiyoruz? Onlarla "Günaydın!" ve "iyi akşamlar!" dan başka konuşacak şeyimiz neden olmuyor, diye hayıflanıyoruz şimdi.

Ha, bakın eski günlerin kapısını aralayacak olursak iş değişir. Onlar, komşularımızla üst üste değil, yan yana oturduğumuz günlerdi. Evlerimizin kesişen noktaları vardı o zamanlar. Küçük, daracık pencerelerimiz birbirine bakardı. Annelerimiz oradan başını uzatır, sonu gelmez sohbetlere koyulurlardı. Evlerimizin şirin, yemyeşil avluları olurdu. Kapımızın önünden akıp geçen su, komşumuzun avlusunu sulardı ve komşu çocuklarıyla, ayaklarımız aynı sudan ıslanırdı mevsimler boyu. Avlularımızdaki iğde yahut söğüt ağaçlarının dalları birbirine değerdi. Yalnız söğüt ve iğde dalları mı? Hayatımız, seslerimiz, bakışlarımız...

"Komşu anne" sözünü duydunuz mu siz hiç? Biz komşu çocukları, birbirimizin annesine "komşu anne" derdik. Anneler, kendi çocuklarına ne almışlarsa bir tane de komşu çocukları için alırlardı. Kardeş gibi büyürdük bitişik evlerde. Oralarda yer içer, yatıya kalırdık. Çocukluğumuz, yarı yarıya komşu evlerinde geçerdi bizim. "Kardeş yarısı" komşu çocuklarıyla oyunlar oynar, kavga eder, barışırdık. Sünnetlerimizi, düğünlerimizi birlikte yapar, birbirimizin açlı̆̆ına ve tokluğuna şahit olurduk. Üzüntülerimizi paylaşırdık. Birbirimizin yemek kokularını duyardık evlerimizden, o yemekleri paylaşırdık. Dost, sırdaş ve nihayet komşuyduk...

Bugün memleketini, çocukluğunu, gençliğini, huyunu ve hatta adını bile bilmediğimiz komşularımızla paylaşacak neyimiz vardır? Oyun oynamadığımız, kavga edip barışmadığımız insanlarla nasıl dost olabiliriz? Onlar bize nasıl inanır, biz onlara nasıl güveniriz? Komşuluk, ortak bir dünyanın ve paylaşılan uzun zamanların hatırasını saklar. Büyük şehirlerde, çoğumuzun başkalarıyla ortak bir dünyası, paylaşacak zamanı yok artık... Hâlâ yan yana duran ve avlularından serin sular akan evlerin bulunduğu, salkım sögüutlerin mütemadiyen bitişik avlulara sarktığı köylerde, kasaba ve şehirlerde komşuluktan söz edilebilir belki...

Ali ÇOLAK

\section{1- Acıklama:}

a) Derse başlamadan önce beynin iyi bir öğrenme gerçekleştirebilmesi için suya ihtiyaç duyduğunu hatırlatınız ve öğrencileri bol su içmeye teşvik ediniz.

b) Öğrencilerin birden fazla seçenek içinden seçebilecekleri sayıda ve onların hareket etmesine imkân veren etkinliklerin kullanılmasını önemseyen beyin temelli öğrenmeye ve yazma becerisinin geliştirilmesine uygun bir teknik olan istasyon tekniğini uygulayınız. 
Tahtaya "Mahallemize Yeni Taşınan Aile" başlığını yazınız. Sınıfın üç ayrı köşesine birbirinden uzak olacak şekilde üç masa (istasyon) yerleştiriniz. İstasyonlara boş kâğıt, renkli kalemler, silgi, karton, makas gibi materyaller koyunuz. Sınıfı üç gruba ayırınız. Öğrencilere her istasyonda ayrı bir görev yapacaklarını söyleyiniz. Her istasyona öğrencilerin içinden bir rehber seçiniz. Düdük çalmanızla birlikte birinci grubu öykü, ikinci grubu şiir, üçüncü grubu resim istasyonuna gönderiniz. Her gruba bulundukları istasyona uygun görevleri yapmaları gerektiğini söyleyiniz. íkinci düdük sesiyle beraber bütün grupların yer değiştirmelerini sağlayınız. Öğrencilere geçtikleri istasyonda başlanan işi devam ettirmelerini söyleyiniz. Üçüncü düdük sesiyle grupların son kez yer değiştirmesini sağlayınız ve gruplara kalan işi tamamlamalarını söyleyiniz. Son düdük sesiyle gruplardan ortaya çıkan ürünleri teslim etmelerini isteyiniz. Öykü ve şiiri sınıfa okuyunuz/okutunuz, resmi ise sınıf panosuna asınız.

\section{2- Motivasyon:}

a) Sınıfa komşuluk ilişkileri ile ilgili yardımlaşma, dostluk, paylaşma vb. unsurları içeren görseller getiriniz ve bunları tahtaya asınız. Öğrencilerden bu görselleri yorumlamalarını isteyiniz.

b) İçinde komşu sözcüğü geçen atasözleri ilgili hazırlanan çalışma kâğıdını öğrencilere dağıtınız.

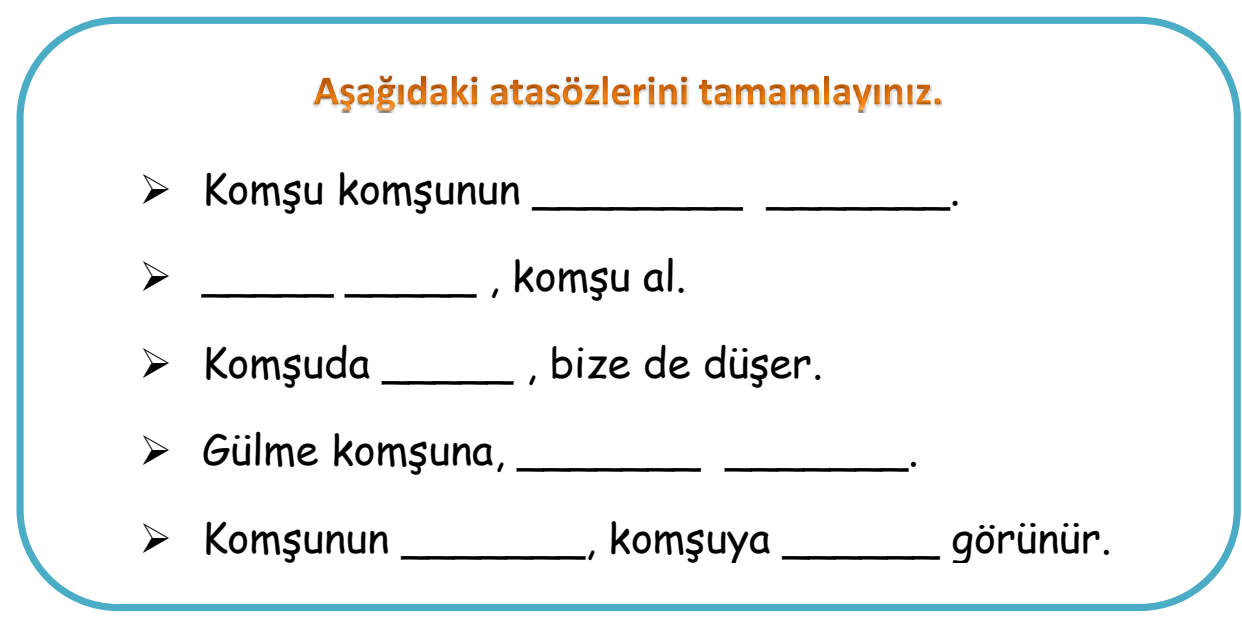

c) Öğrencilerin konu ile geçmiş ve günlük yaşantıları arasında bağ kurabilmesi amacıyla öğrencilere "Apartman da mı müstakil bir evde mi oturuyorsunuz?, Ailenizle birlikte komşuları ziyarete gidiyor musunuz? , Daha önce hiç annenizin yaptığı yemeği bir komşunuza götürdünüz mü? , Daha önce hiç komşularınızın çocuklarıyla bir araya gelip oyun oynadınız mı?" sorularını yöneltiniz.

d) Sağladığı eğlenceli ortam ve dil becerilerini etkin kılmasıyla beynin sol yarım küresini; hayal kurmayı, yeniliklere açık olmayı ve yaratıcı düşünmeyi teşvik etmesiyle de beynin sağ yarım küresini harekete geçiren beyin fırtınası tekniğini uygulayınız.

Tahtaya "Şehirlerdeki komşuluk ilişkilerini canlandırmak için neler yapabiliriz?" sorusunu yazınız. Öğrencilere fikirlerini sorunuz ve söz alanlardan tahtaya gelerek fikirlerini yazmalarını isteyiniz. Uygulama süreci boyunca birbirinden farklı olan her önerinin yazılmasına dikkat ediniz. Fikir alma süreci bittikten sonra öne sürülen fikirleri sınıflandırınız ve öğrencilerle birlikte değerlendiriniz.

e) Öğrencilerin ilgisini çekmek için konuyla ilişkili kısa bir hikâye okuyunuz. Hikâyeyi okuduktan sonra öğrencilerden "Ben olsaydım nasıl yazardım?" düşüncesinden hareketle metni kendi ifadeleriyle yeniden kurgulayıp yazmalarını isteyiniz. 
Osmanlı veziriazamlarından Hekimoğlu Ali Paşa, çok cömert ve hâl ehli bir zat idi. Onun komşularından biri, paraya ihtiyacı olduğundan, evini satılığa çıkardı. "Kaça veriyorsun?" dediler. "Yüz bin akçeye" dedi. "Senin bu küçük evin o kadar eder mi?" dediklerinde; "Ya siz, Hekimoğlu Ali Paşa'nın komşuluğunu kaça almak istiyorsunuz?" dedi. "Komşu satın alınır mı?" dediklerinde, "Ev komşu için alınır. İyi bir komşu bir şey istenildiğinde memnuniyetle hemen verir. İstenilmezse bir şey lâzım mı? diye sorar. Kendisine kötülük edene iyilik eder. İşte Hekimoğlu Ali Paşa da bunlardan biridir. Böyle bir komşuya sahip olmak için evime yüz bin akçe çok mudur?" Bu söz Hekimoğlu Ali Paşa'nın kulağına gidince bir hayli para verdi ve: "Bununla ihtiyacını gider, evini satma. Senin gibi kadirşinas komşudan ayrılmak istemiyorum." dedi.

\section{SIZ OLSAYDINIZ BU HIKÂYEYI NASIL YAZARDINIZ?}

\section{3- Başlama ve Edinim:}

a) Öğrencilerin çağrışımlardan yola çıkarak yazmalarını sağlamak amacıyla hazırlanan çalışma kâğıdını dağıtınız. Öğrencilere "Komşu" sözcüğünün zihninizde uyandırdığı sözcükler nelerdir?" sorusunu yöneltiniz ve zihinlerine gelen sözcükleri dağıtılan çalışma kâğıdına yazmalarını söyleyiniz. Daha sonra öğrencilerden bu sözcükleri kullanarak bir paragraf oluşturmalarını isteyiniz.

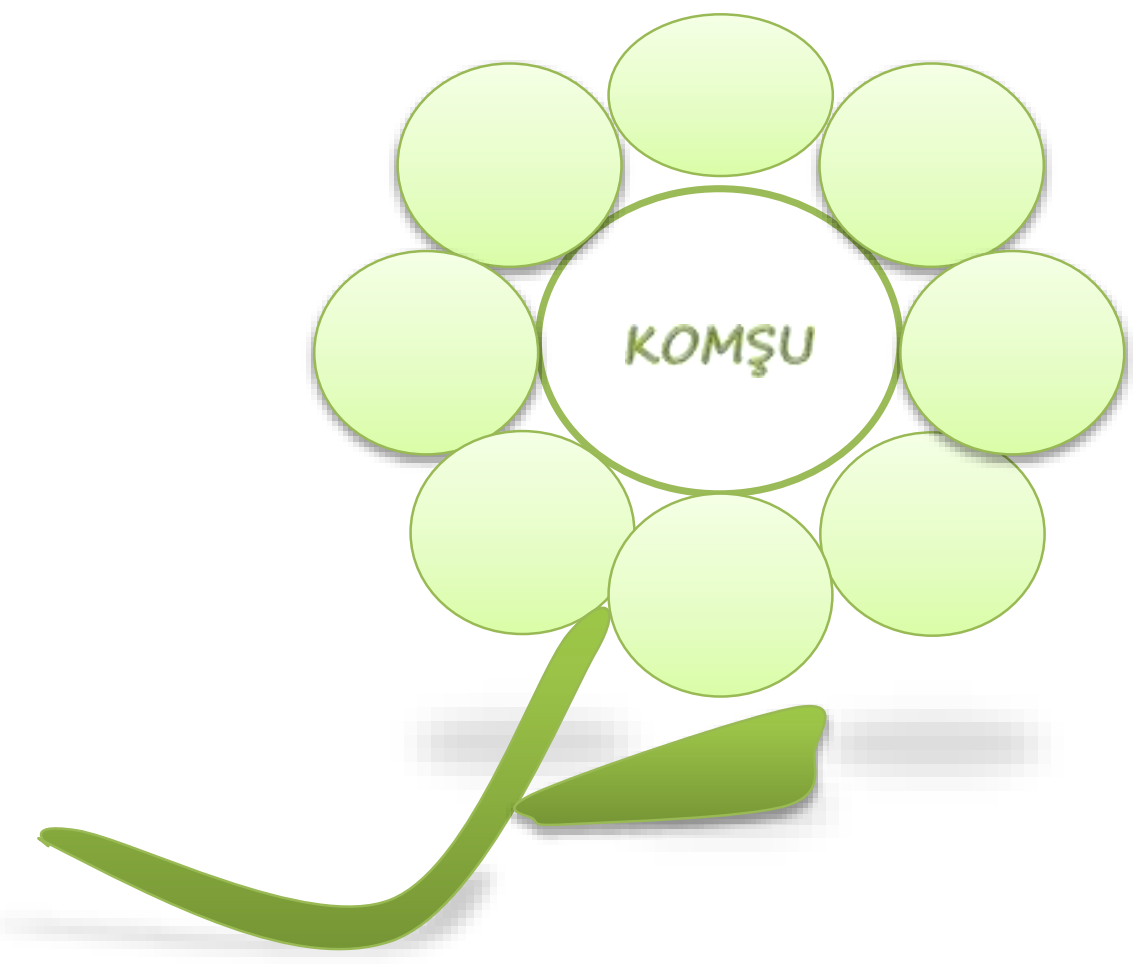




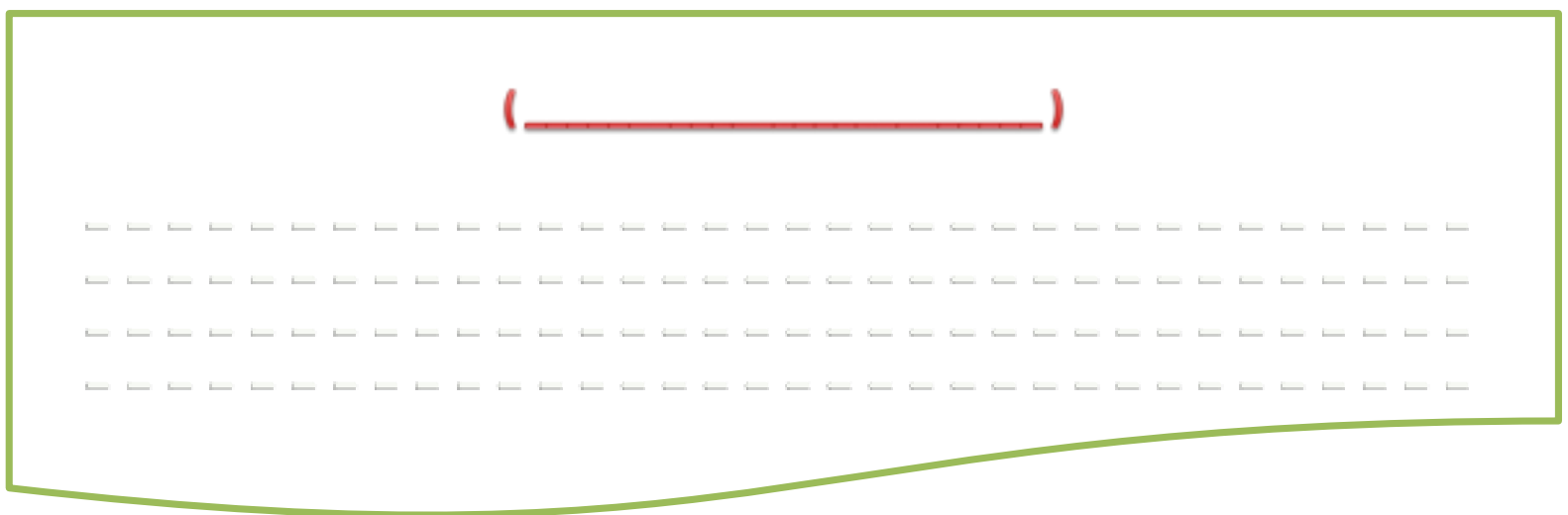

b) Öğrencilere "Komşusuzluk" adlı metnin görsellerini incelemelerini ve metnin başlığına odaklanmalarını söyleyiniz. Öğrencilerden görsellerden ve metnin başlı̆̆ından hareketle içeriği tahmin etmelerini isteyiniz.

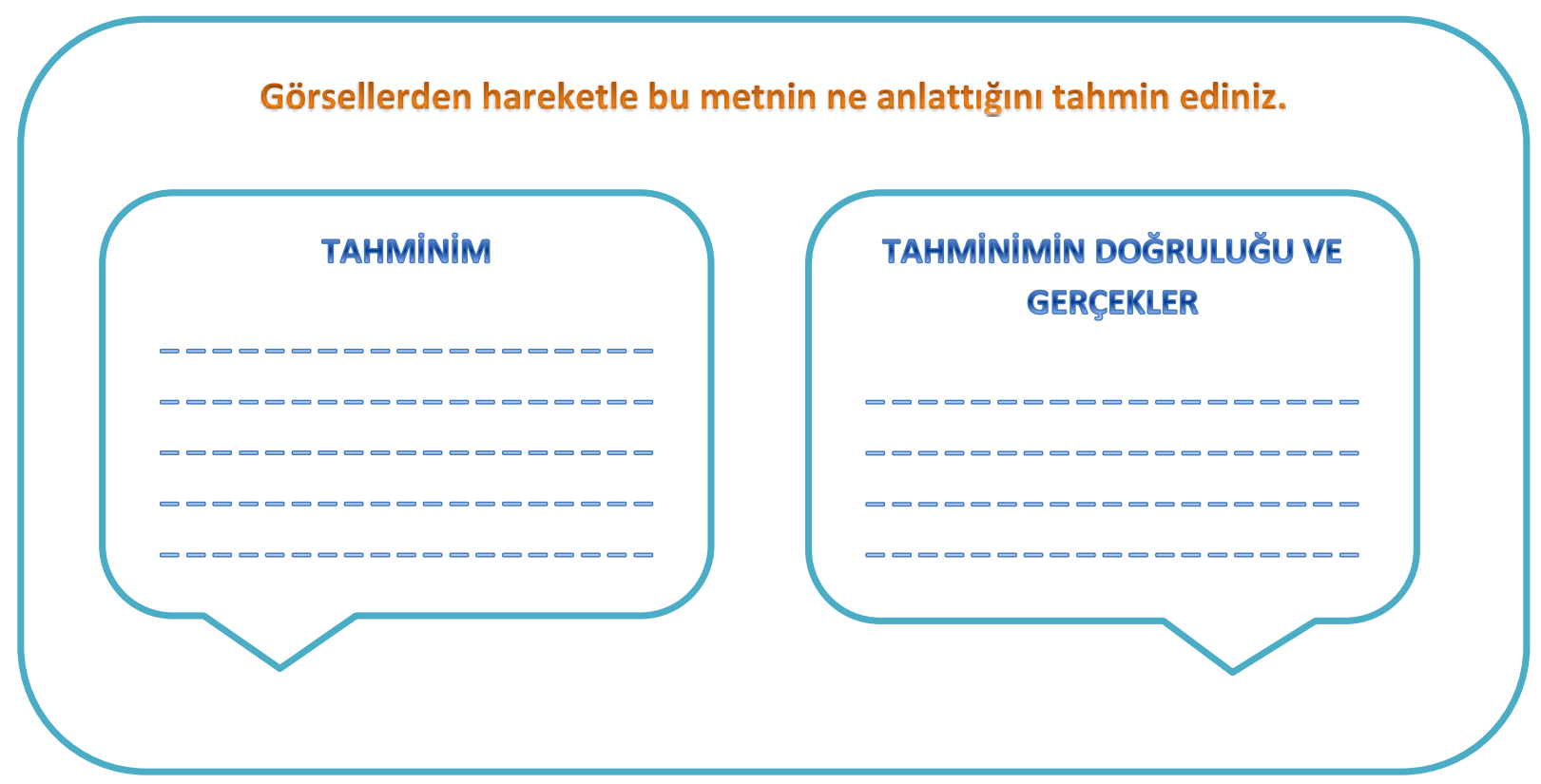

c) "Komşusuzluk" adlı metnin, öğrencilerin okuma sürecinde aktif bir şekilde yer almasını sağlayan ve yazma becerilerinin de gelişmesine imkân veren özetleyerek okuma yöntemiyle okunacağını öğrencilere söyleyiniz. Tahtaya "Metinde geçen şahıslar kimlerdir?” , "Olaylar nerede ve ne zaman geçmektedir?” yazınız. Öğrencilerden metni dinlerken bu soruların cevaplarını bulmaya çalışmalarını isteyiniz. Metni sesli okumaya başlayınız. Giriş bölümünün sonunda okumayı bırakarak öğrencilere okunan bölümün özetini çıkarmaları için beş dakika süre veriniz. Aynı işlemleri gelişme ve sonuç bölümleri için de tekrarlayınız. Okuma bittikten sonra, öğrencilerden her bölümün özetini birkaç cümleyle yeniden ifade etmelerini ve bu cümleleri birleştirerek tek bir paragraf oluşturmalarını isteyiniz. Metni ikinci kez duraklamadan okuyunuz. Öğrencilerin özetlerinde gerekli düzeltmeleri yapmalarını sağlayınız.

ç) Okuma tamamlandıktan sonra "Metnin başkahramanı en çok neden yakınmaktadır?" , "Yazar özel bir gün olarak komşular gününe neden karşı çıkmaktadır?” , "Metinde eski komşuluklar nasıl 
anlatılmaktadır?” , “Yazara göre günümüzde komşuluktan nerelerde söz edilebilir?” sorularını yöneltiniz.

d) Öğrencilerden metni okumadan önce yaptıkları tahminin doğruluğunu kontrol etmelerini ve metnin içeriği ile ilgili bilgileri, dağıtılan çalışma kâğıdına yazmalarını isteyiniz.

e) Öğrencilerden metnin konusunu ve ana fikrini yazmalarını isteyiniz.

f) Öğrencilere metindeki bilinmeyen kelimelerle ilgili çalışma yaptırmak üzere hazırlanan çalışma kâğıdını dağıtınız.

\section{Aşağıdaki metinde geçen kelime ve kelime gruplarını anlamlarıyla eşleştiriniz.}

1. Yâd etmek

2. Hayıflanmak

3. Mütemadiyen

4. Müşteki

5. Akıbet a. Şikâyetçi, yakınan

b. Sürekli, ara vermeden

c. Anmak, hatirlamak

d. Bir iş veya durumun sonu, sonuç

e. Kaybedilen bir firsat için üzülmek

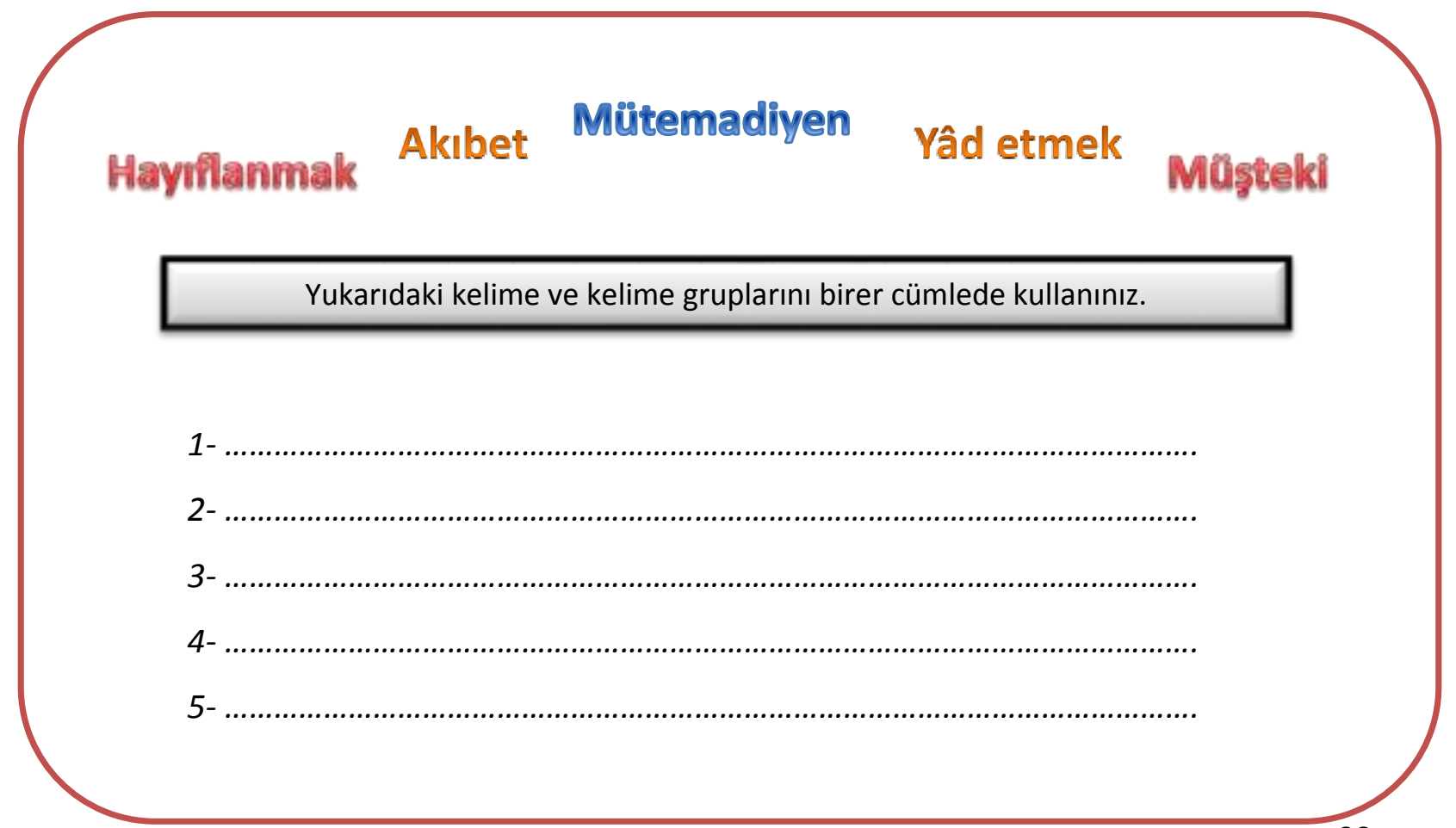


g) Öğrencilerinize yaratıcı düşünme ve aktif katıım gerektiren bir etkinlik olan afiş hazırlama etkinliği ile ilgili olarak hazırlanan çalışma kâğıdını dağıtınız ve onları beşerli gruplara ayırınız. Öğrencilere, yaşadıkları mahallede bütün komşuların bir araya geleceği bir etkinlik planlandı̆̆ını; bu etkinliğin amacının mahalledeki komşuluk ilişkilerini güçlendirmek, mahalleye yeni taşınanlarla orada uzun süredir yaşayanları tanıştırmak ve kaynaştırmak olduğunu; onlardan da bu etkinliği duyurmak ve mahalle sakinlerini davet etmek için etkileyici sloganı olan bir afiş hazırlamaları istendiğini söyleyiniz. Ortaya konulan ürünlerin sınıfta sergileneceğini belirtiniz.

h) Metinde geçen kelimeleri küçük kâğıtlara yazınız ve bir torbanın içine koyunuz. Sınıfı dört gruba ayırınız. Her grubun bu torbadan rastgele 'altışar' kelime seçmesini sağlayınız. Gruplardan seçtikleri kelimeleri kullanarak anlamlı bir metin oluşturmalarını isteyiniz. Oluşturulacak metinlerin sınıf panosunda sergileneceğini belirtiniz. Metin yazımı tamamlandıktan sonra her gruptan bir öğrencinin metni okumasını sağlayınız.

Apartman, Asansör, Anahtar, Komşu, Yabanci, Posta Kutusu, Yalnızlık, Hatıra, Eski Günler, Pencere, Avlu, Mevsim, Komşu Anne, Kardeş Yarısı, Dost, Düğ̈̈n, Sünnet, Cocuk, Ouun, Kavaa, Barısmak, Güvenmek, Paulasmak.

\section{4- Ayrıntıya Girme:}

a) Öğrencilere "Metinde geçen 'Insanın yakınında bir komşusunun olduğunu bilmesi hatta ona kızabilmesi bile güzel şey!' cümlesi size ne ifade ediyor?” , "Metinde komşuluk ilişkilerinin hayatımızdan yavaş yavaş çıktığı belirtiliyor. Bu konuda siz neler düşünüyorsunuz?” , "Size göre komşuluk ilişkilerinin zayıflamasının nedenleri nelerdir?" sorularını sorunuz.

b) Öğrencilerden 'Boş Arsa' adlı metne yeni bir başlık bulmalarını isteyiniz.

c) İyi Komşu Kötü Komşu adlı metnin cümlelerinin sırasını değiştirerek öğrencilere dağıınız. Karışık olarak verilen cümlelerden anlamlı bir metin oluşturmalarını isteyiniz.

\section{İY் KOMŞU KÖTÜ KOMŞU}

A) Yengeç onun bu hâline bakmış bakmış:

B) Ama kötülük yılanın kanında var, durur mu?

C) Yılanla yengeç komşuymuş.

Ç) Yengeç bakmış olacak gibi değil, sonunda, uyurken yılanı kıskıvrak bastırmış, öldürüvermiş. Kıvır kıvır yılan, ölünce ip gibi upuzun, dosdoğru uzanmış kalmış.

D) Kötüler yaşarken herkesi canından bezdirirler.

E) -Bak, biz komşuyuz. Birbirimize kötülük etmeden geçinip gidelim. Kötülükten ne sana yarar gelir ne bana, dermiş.

F) -Be yılan, demiş. Bu uysallığını, bu dosdoğruluğunu sağken gösterseydin de şimdi ölmeseydin olmaz mıydı?

G) İyi komşu yengeç, ikide bir yılanı uyarırmış:

Ğ) -Ah. bir acıăını bulsam da su venaecin hakkından aeliversem. ne aüzel olur! dive düsünürmüs. 


\begin{tabular}{|c|c|c|c|c|c|c|c|c|}
\hline 1 & 2 & 3 & 4 & 5 & 6 & 7 & 8 & 9 \\
\hline C & G & E & B & G & Ç & A & F & D \\
\hline
\end{tabular}

d) Sınıfı dört gruba ayırınız. Her gruba konuyla ilgili olabilecek resimler dağıtınız. Öğrencilerden grup arkadaşları ile birlikte resimleri incelemelerini isteyiniz. Öğrencilere bu resimlerin Komşusuzluk adlı metindeki hangi paragraflarla ilişkisi olabileceğini sorunuz. Her gruptan resimlerle ilgili bir hikâye oluşturmalarını isteyiniz. Oluşturdukları hikâyede ana karakter, yer, olay ve zamana yer vermeleri gerektiğini belirtiniz. Gruplara yirmi dakika süre veriniz. Süre bitiminde her gruptan bir öğrencinin oluşturdukları hikâyeyi okumasını isteyiniz. Gruplara "Hikâye Haritam" adlı çalışma yaprağını dağıınız ve doldurmalarını isteyiniz.

\section{HIKÂYE HARITAM}

\section{HIKÂYENIN ADI}

ANA KARAKTER

- - - - - - - - - - - -

\section{YARDIMCI KARAKTERLER}

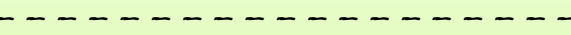

\section{OLAYIN GEÇTIĞi YER}

\section{OLAYIN GECTTIĞi ZAMAN}

\section{OLAY}


e) Öğrencileri üç gruba ayırınız. "Mahallemizde geniş bahçeli bir evde oturan ve kimseyle konuşmayan gizemli bir komşumuz vardı." cümlesinin yazılı olduğu kâğıtları gruplara dağıtınız. Öğrencilere önceki cümleyle anlam ve dil bilgisi açısından uyumlu olması koşuluyla her birinin bir önceki cümleye yeni bir cümle eklemesi gerektiğini söyleyiniz. Her öğrenciden cümlesini yazdıktan sonra kâğıdı yanındaki arkadaşına vermesini isteyiniz. Yazılacak metinlerin okunacağını ve panoya asılacağını belirtiniz. Bütün öğrenciler bir cümle yazdıktan sonra oluşturulan metinleri toplayınız.

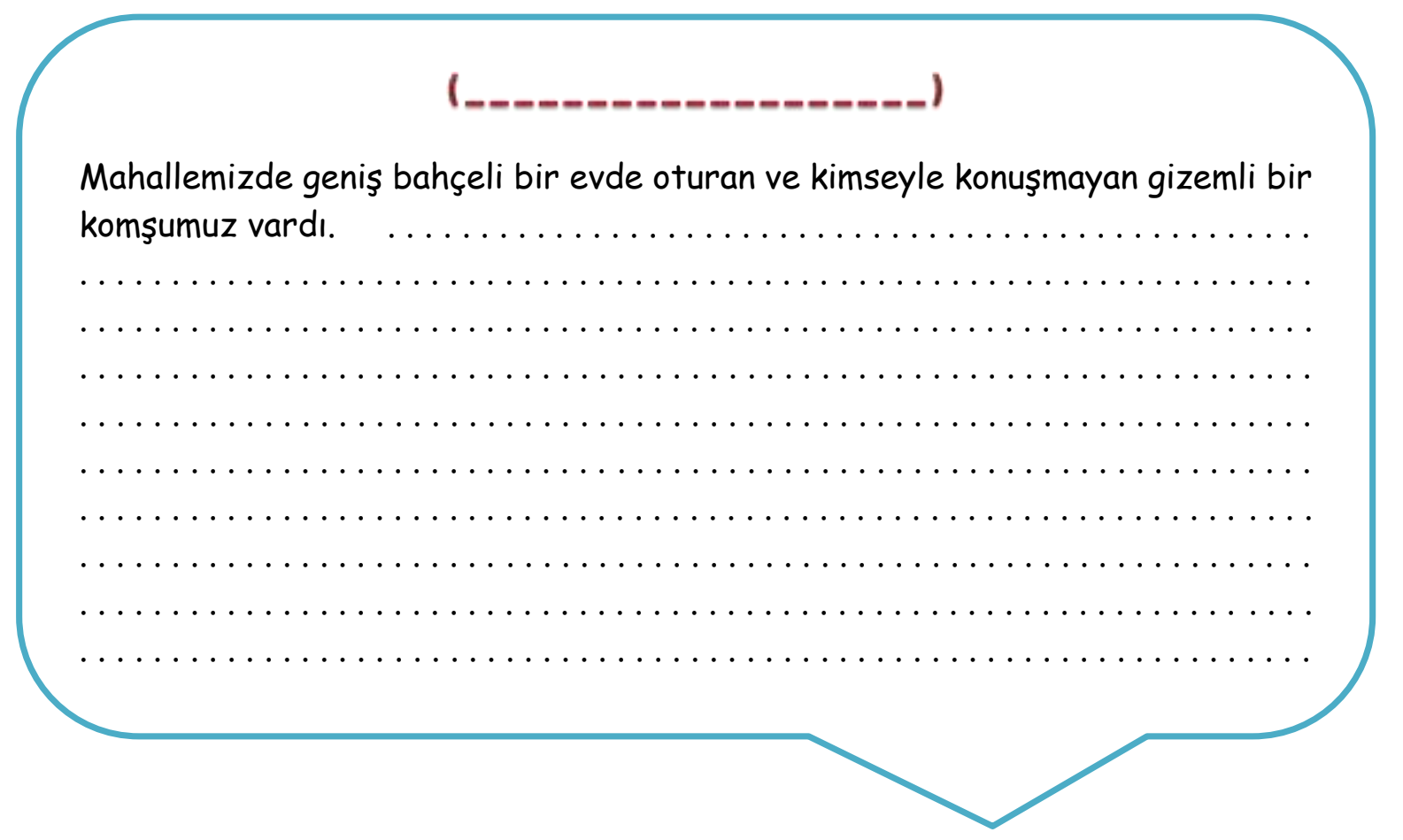

\section{5- Belleğe Kodlama:}

Derse bir süre ara veriniz ve müzik açınız. Dinleme sırasında öğrencilere gözlerini kapatmalarını ve müziğin onlara neler çağrıştırdığını düşünmelerini söyleyiniz. Dinleme bittikten sonra öğrencilere “Müziği dinlerken neler hissettiniz?” , "Bu müzik size neler çağrıştırdı?” , "Müziği dinlerken neler düşündünüz?" sorularını yönelterek onlardan duygu ve düşüncelerini yazılı biçimde ifade etmelerini isteyiniz. Daha sonra öğrencileri bahçeye çıkarınız. Onlardan ikili gruplara ayrılarak bahçede dolaşmalarını ve öğrendikleri konuyla ilgili birbirleriyle fikir alışverişinde bulunmalarını isteyiniz.

\section{6- Doğrulama ve Öz Güven Kontrolü:}

a) Öğrencilere yaşadıkları çevredeki komşuluk ilişkilerini gözlemlemelerini ve anne babalarının varsa büyükanne ve büyükbabalarının bu konudaki fikirlerini almalarını söyleyiniz. Öğrencilerden ailedeki büyüklerine "Eskiden komşuluk ilişkileri nasıldı?" sorusunu sormalarını ve onların anlattıklarını yazarak sınıfa getirmelerini isteyiniz. Sınıfa getirilen metinleri öğrencilere okutunuz.

b) Öğrencilerden “Elli yaşına geldiğinizde sizce komşuluk ilişkileri nasıl olacak?” sorusundan yola çıkarak bir metin oluşturmalarını isteyiniz. Yazılan metinleri sınıfta okutunuz ve öğrencilerin birbirini değerlendirmesini sağlayınız. 


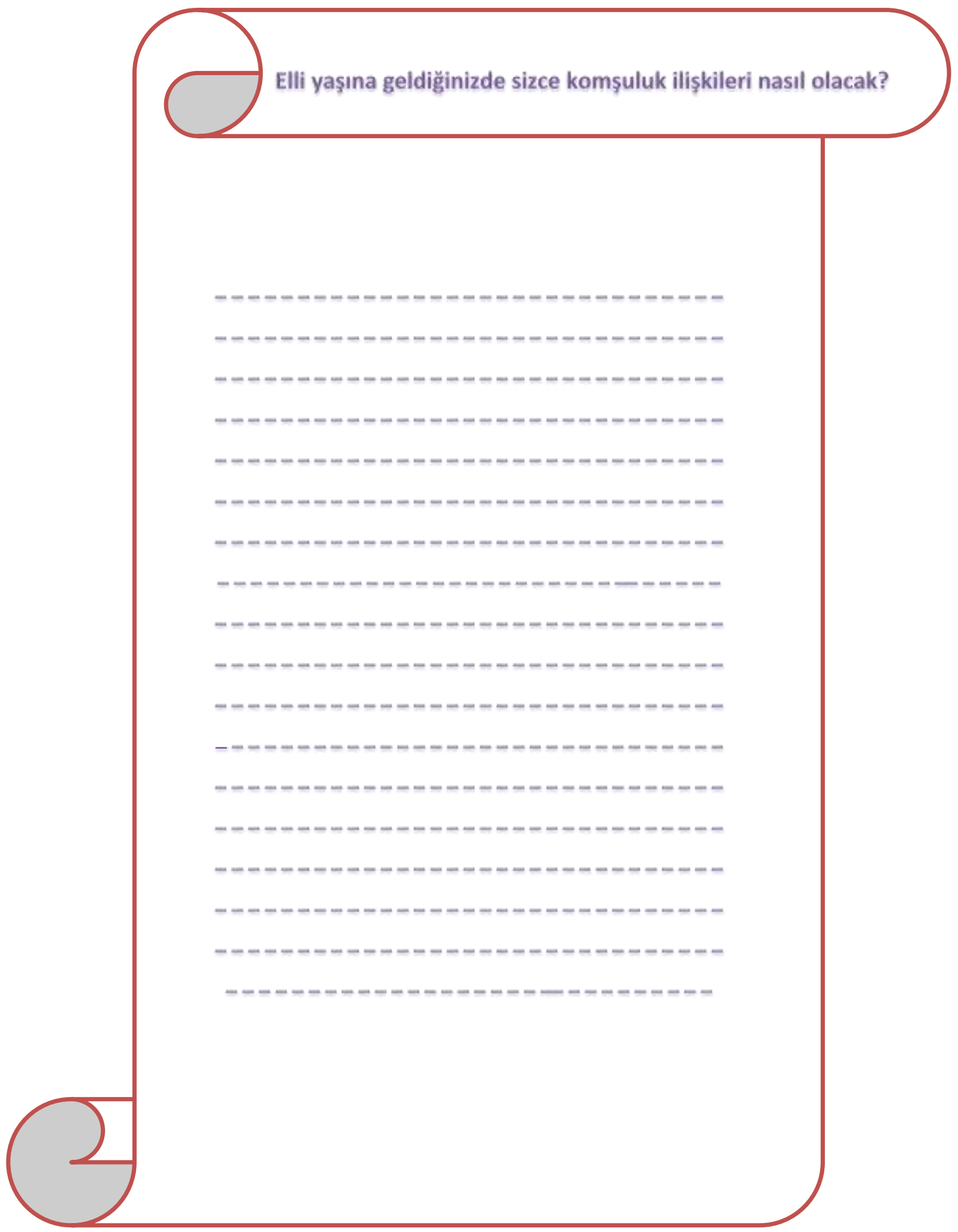

c) Öğrencilere "Metinden Öğrendiklerim" adlı çalışma kâğıdını dağıtınız. Öğrendiklerini bu kâğıda yazmalarını ve arkadaşlarına okumalarını isteyiniz.

ç) Öğrencilere akran değerlendirme formunu dağıtınız. 


\section{AKRAN DEĞERLENDIRME FORMU}

Bu form, ders süreci boyunca birlikte çalıştığınız bir arkadaşınızla ilgili değerlendirme yapmanız için size verilmiştir. Seçeneklerden en uygun olanını işaretleyiniz.

Değerlendirdiğiniz arkadaşınızın;

Adı ve Soyadı:

Her zaman Bazen $\quad \begin{aligned} & \text { Hiçbir } \\ & \text { zaman }\end{aligned}$

1. Grupla uyumlu çalıştı.

2. Çalışmalardaki görevlerini yerine getirdi.

3. Çalışmalara istekli bir şekilde katıldı.

4. Çalışma öncesinde gerekli hazırlıkları yaptı.

5. Gruptaki diğer arkadaşların fikirlerine saygı duydu.

6. Kendi fikirlerini açıkça dile getirdi.

7. Yaratıcı fikirler ve çözümler üretti.

8. Gerektiğinde sorumluluk aldı.

9. Temiz ve düzenli çalıştı.

10. Türkçeyi doğru, güzel ve etkili kullandı.

\section{7- Kutlama:}

a) Ders süreci boyunca öğrencilerin ortaya koyduğu ürünlerin sınıfta sergilenmesini sağlayınız. Sınıf ortamını öğrencilerin eğlenmesine imkân verecek şekilde düzenleyiniz. Öğrencilerin kısa ve sade bir kutlama yapmalarını sağlayınız.

\section{Sonuç}

Eğitimde ortaya çıkan yeni yaklaşımların tanınması, benimsenmesi, uygulanması belli bir süre almakta ve yaklaşımlar bu süreçte birtakım zorluklarla karşılaşmaktadır. Bu zorluklardan birisi de yaklaşımın farklı eğitim alanlarına uyarlanmasıdır. Beyin araştırmalarına dayalı öğrenme yaklaşımı son yüzyılda ortaya çıkmış yeni bir yaklaşım olduğu için birçok alana olduğu gibi Türkçe eğitimi alanına da 
henüz uyarlanmamıştır. Bu çalışmada hazırlanan uygulama örneğinin yaklaşımın Türkçe eğitimi alanına yerleşmesine katkı sağlayacağı düşünülmektedir.

\section{Kaynakça}

Açıkgöz, Ü. K. (2003). Etkili Öğrenme ve Öğretme. İzmir: Eğitim Dünyası Yayınları.

Akpınar, B. ve Gezer, B. (2010) Öğrenen Merkezli Yeni Eğitim Yaklaşımlarının Öğrenme-Öğretme Sürecine Yansımaları, Dicle Üniversitesi Ziya Gökalp Eğitim Fakültesi Dergisi. 14, 1-12.

Bursky, D. (2002). Engineering education must teach a worldwide view. Electronic Design. 50, 1-22.

Caine, R. N. ve Caine, G. (1990). Understanding A Brain Based Approach to Learning and Teaching. Educational Leadership, October. p. 66- 71.

Caine, R. N. ve Caine, G. (1991). Making Connections: Teaching and the Human Brain. Alexendria VA: Association for Supervision and Curriculum Development.

Caine R. N. \& Caine G. (1995). Reinventing Schools Through Brain-Based Learning, Mindshifts, Tucson.

Carolyn, R. P. (1997). Brain-Based Learning and Students. The Education Digest Ann Arbor, 63(3), 10-15.

Connell, D. (2009). The Global Aspects of Brain Based Learning. Educational Horizons, Fall p.28-38.

Çolak, A. (2013). ince Sözler. İstanbul: Ötüken Neşriyat.

Demir, T. (2012). Türkçe Eğitiminde Yaratıcı Yazma Becerisini Geliştirme ve Küçerek Öykü. Mustafa Kemal Üniversitesi Sosyal Bilimler Enstitüsü Dergisi. 9(19), 343-357.

Demirel, Ö. (1999). illköğretim Okullarında Türkçe Öğretimi. İstanbul: MEB Yayınları.

Dhority, L. F. ve Jensen, E. (1998). Joyful Fluency: Brain Compatible Second Language Acquisition. San Diego: The Brain Store Inc.

Duman, B. (2007). Neden Beyin Temelli Öğrenme? Ankara: Pegem A Yayıncılık.

Göçer, A. (2010). Türkçe Öğretiminde Yazma Eğitimi. Uluslararası Sosyal Araştırmalar Dergisi 3(12), 178-195.

Göğüş, B. (1978). Orta Dereceli Okullarımızda Türkçe ve Yazın Eğitimi. Ankara: Kadığlu Matbaacılık.

Güneş, F. (2007). Türkçe Öğretimi ve Zihinsel Yapılandırma. Ankara: Nobel Yayın Dağııım.

Jensen, E. (2000). Brain Based Learning. San Diego CA: Brain Store Publishing.

Jensen, E. (2008). Brain-Based Learning: The New Paradigm of Teaching, 2nd Edition, Corwin Press, California: United States of America.

MEB (2006). Ilköğretim Türkçe Dersi 6-8. Sınıflar Öğretim Programı. Ankara: MEB Yayınları.

Neuangchalerm, P. ve Charnsirirattana, D. (2010). A Delphi Study on Brain Based Instructional Model in Science. Canadian Social Science, 6 (4), 141- 146.

Okurer, C. (1997). Kompozisyon Öğretimi. İstanbul: MEB Yayınları.

Özbay, M. (2011). Türkçe Özel Öğretim Yöntemleri Il. Ankara: Öncü Basımevi.

Polat, M. (2014). Beyin Temelli Öğrenmenin Açılımı Nedir?. Eğitim ve Öğretim Araştırmaları Dergisi, 3(2), 265274.

Şenatalar, B. (2004). Öğretim Etiği, Araştırma Etiği ve Yönetim Etiği. Nasıl Bir Üniversite (Editör: C. Can Aktan). İstanbul: Değişim Yayınları.

Yılmaz, Y. (2006). Yazma Öğretimi (ss.203-276), Kuramdan Uygulamaya Türkçe Öğretimi (Editör: Cemal Yıldız). Ankara: Pegem A Yayıncılık. 